\title{
Defence, Denial or Cause of Action? 'Enrichment Owed' and the Absence of a Legal Ground
}

Helen Scott*

\section{Defences and Denials}

The distinction between defences and denials proposed by James Goudkamp in his recent book Tort Law Defences is an extremely useful analytical tool in the hands of tort lawyers. ${ }^{1}$ According to his typology, the term 'defence' refers to a rule that, when enlivened, results in a verdict for the defendant even though all the ingredients of the tort in which the claimant sues are present. ${ }^{2}$ By contrast, a denial is a plea by the defendant that one of the elements of the tort in which the claimant sues is absent; it does not introduce into the proceedings any issue that the claimant will not already have put in contention. ${ }^{3}$ Thus, the definition of tort defences is for Goudkamp a substantive rather than a procedural question, in the sense that it does not turn on the distribution of the burden of proof between the parties. ${ }^{4}$ Admittedly, there remains a close correspondence between defences and the burden of proof: it is almost always for the defendant to plead and prove a defence. ${ }^{5}$ Nevertheless, according to his typology, the distinction between actions and defences, and more specifically denials and defences, turns on substantive arguments about the definition of torts.

The distinction between denials and defences has now been extended by James Goudkamp and Charles Mitchell to the law of unjust enrichment. ${ }^{6}$ As in the context of tort, here the term 'denial' refers to any argument by the defendant that liability should not be imposed because one or more of the elements of the claimant's action is missing, ${ }^{7}$ whereas

\footnotetext{
* Department of Private Law, University of Cape Town. This essay is published in A Dyson, J Goudkamp and F Wilmot-Smith, Defences in Unjust Enrichment (Oxford, Hart Publishing, 2016) ch 3. I am grateful to the participants in the seminar which gave rise to this collection, held at All Souls College in January 2015, for their very helpful comments.

${ }^{1}$ J Goudkamp, Tort Law Defences (Oxford, Hart Publishing, 2013).

2 ibid 2.

3 ibid.

4 ibid 3-4. cf E Descheemaeker, 'Tort Law Defences: A Defence of Conventionalism' (2014) 77 MLR 493, especially 497-99.

${ }^{5}$ Goudkamp (n 1) 47.

${ }^{6}$ J Goudkamp and C Mitchell, 'Denials and Defences in the Law of Unjust Enrichment' in C Mitchell and W Swadling (eds), The Restatement Third: Restitution and Unjust Enrichment (Oxford, Hart Publishing, 2013) ch 6.

${ }^{7}$ ibid 137.
} 
the term 'defence' refers specifically to a rule enabling the defendant to be wholly or partly relieved of liability which is independent of or extrinsic to the claimant's action. ${ }^{8}$ Here, too, defences are defined independently of the distribution of the burden of pleading and proof. ${ }^{9}$ Under the heading 'Rationalising the Distinction between Actions and Defences', Goudkamp and Mitchell discuss a number of possible justifications for the existence of defences in the law of unjust enrichment. ${ }^{10}$ These are all more or less instrumental arguments and all five are general in nature, appropriate not only to the unjust enrichment context but also to tort. ${ }^{11}$ Goudkamp and Mitchell claim, further, that: 'If the distinction between actions and defences is justifiable, the rationale or rationales that support it may bear upon how rules that govern liability should be classified.' ${ }^{12}$ In other words, these general, instrumental arguments may also inform the classification of particular legal institutions either as elements in the claimant's action or as defences.

However, at the risk of lapsing into circularity, it seems that if Goudkamp's definition of defences is correct, then the basis for characterising a particular legal institution as a defence must be whether the institution in question is indeed judged to be extrinsic to the claimant's action. This is surely an exercise informed by doctrinal and moral arguments specific to the unjust enrichment context, not instrumental arguments of relatively general application. ${ }^{13}$ We ask ourselves whether our account of the institution is consistent with judicial dicta, whether it coheres with other features of the law of unjust enrichment as a whole, and whether an account of the claimant's action which excludes the institution in question is convincing in light of the law's internal values. Thus, the recognition of the distinction between actions and defences, and denials and defences in particular, assists in answering fundamental questions about the nature of claims in unjust enrichment. It forces us to think carefully about the normative basis of such claims.

\section{Is 'Enrichment Owed' a Defence or a Denial in English Law?}

These introductory remarks lead directly to the central question addressed by this chapter, namely whether a plea that a particular benefit was owed to the defendant under a valid contractual, statutory or other legal obligation constitutes a defence or a denial according to

\footnotetext{
8 ibid 137-38. Again, as in the case of tort, it is admittedly the case that rules that qualify as defences in the second sense must generally be pleaded and proved by the defendant, limitation being a notable exception: see ibid 138.

9 ibid $137-39$.

10 ibid $146-50$.

${ }^{11} c f$ the high degree of overlap between the justifications listed by Goudkamp and Mitchell in ibid and those listed by Goudkamp (n 1) 36-41.

12 Goudkamp and Mitchell (n 6) 149.

13 cf R Grantham and C Rickett, 'A Normative Account of Defences to Restitutionary Liability' (2008) 67

Cambridge Law Journal 92, especially 94-96.
} 
the English law of unjust enrichment. In the introductory chapter of Unjust Enrichment in South Africa Law: Rethinking Enrichment by Transfer, published in 2013, I make the following broad claim:

The first category [of unjust factors] reflects the idea that the impoverished party did not mean to transfer the benefit in question: that its conferral was in some sense involuntary. Mistake occupies a central position within this family of unjust factors. According to Birks' approach, mistake is itself the plaintiff's cause of action: the vitiation of his intent in making the transfer is the reason why it must be returned. The presence of a valid contract, statutory obligation or other relationship of indebtedness, such as a judgment debt, has the effect of blocking restitution. However, according to prevailing orthodoxy, this is simply a defence (or a range of defences) by means of which the recipient can defeat this prima facie claim. It enjoys no analytical significance in itself. ${ }^{14}$

A footnote to the sentence in which it is claimed that ' $t$ t]he presence of a valid contract, statutory obligation or other relationship of indebtedness, such as a judgment debt, has the effect of blocking restitution' includes reference inter alia to 'the seminal decision' in Barclays Bank Ltd $v$ WJ Simms Son and Cooke (Southern) $L t d,{ }^{15}$ as well as the more recent decision of the Court of Appeal in Test Claimants in the Franked Investment Income Litigation $v$ Revenue and Customs Commissioners. ${ }^{16}$ It had at one stage $^{17}$ been uncontroversial to confine the issue of 'enrichment owed' to the context of the defence of good consideration first recognised by Robert Goff J in the Simms case, a separate, general defence dealt with in a single chapter of Goff \& Jones alongside other straightforward defences such as change of position. ${ }^{18}$ But the fact that the last two sentences of the passage-in which it is claimed that '[a valid contract, statutory obligation or other relationship of indebtedness] is simply a defence ... by means of which the recipient can defeat this prima facie claim' and 'enjoys no analytical significance in itself'-are heavily qualified by authorities cited in a further footnote ${ }^{19}$ shows that at the time of publication,

14 H Scott, Unjust Enrichment in South African Law: Rethinking Enrichment by Transfer (Oxford, Hart Publishing, 2013) 13 (footnotes omitted).

${ }^{15}$ Barclays Bank Ltd v WJ Simms Son and Cooke (Southern) Ltd [1980] 1 QB 677 (QBD) 695.

${ }^{16}$ Test Claimants in the Franked Investment Income Litigation v Revenue and Customs Commissioners [2010] EWCA Civ 103; [2010] STC 1251 [175]-[184].

${ }^{17}$ And certainly when I began work on my DPhil in 2002.

${ }^{18}$ G Jones, Goff \& Jones: The Law of Restitution, 7th edn (London, Sweet \& Maxwell, 2006) ch 41. See also, eg, G Virgo, The Principles of the Law of Restitution (Oxford, Oxford University Press, 2006) 172-76, where good consideration is treated as a defence specific to mistake claims. For a general account of the treatment of the defence of good consideration by academic commentators, see A Burrows, 'Is There a Defence of Good Consideration?' in Mitchell and Swadling (n 6) ch 7, 166-68.

${ }^{19}$ A Burrows, The Law of Restitution, 3rd edn (Oxford, Oxford University Press, 2011) 88-91; R Stevens, 'Is There a Law of Unjust Enrichment?' in S Degeling and J Edelman (eds), Unjust Enrichment in Commercial Law (Sydney, Thomson Reuters, 2008); G Virgo, 'Demolishing the Pyramid: The Presence of Basis and RiskTaking in the Law of Unjust Enrichment' in A Robertson and T Hang Wu (eds), The Goals of Private Law (Oxford, Hart Publishing, 2009); C Mitchell, P Mitchell and S Watterson, Goff \& Jones: The Law of Unjust 
these claims were becoming increasingly difficult to describe as orthodox. Indeed, as Andrew Burrows has shown, the status of the defence of good consideration in English law is extremely unclear. ${ }^{20}$

In my view, the contemporary debate regarding the basis of liability in the modern English law of unjust enrichment can be neatly summarised as a debate about whether 'enrichment owed' constitutes a defence or a denial according to Goudkamp's definitions: is it extrinsic to the claimant's action or does it speak to one of the elements of the claim? These are, of course, that the defendant has been enriched, that this enrichment was gained at the claimant's expense and that the defendant's enrichment is unjust. ${ }^{21}$ Burrows himself reaches the conclusion that 'enrichment owed' is an 'upfront' matter which relates to prima facie liability-in other words, that it is a denial22 - and in particular that it relates to the third element of the claim, that the enrichment is unjust. ${ }^{23}$ He bases this conclusion in the first instance on several important judicial dicta. According to Lord Hope in Kleinwort Benson Ltd $v$ Lincoln CC, 'the payee cannot be said to have been unjustly enriched if he was entitled to receive the sum paid to him' ${ }^{24}$ This clearly suggests that the payee's entitlement to the sum paid goes to the 'unjust' element of the claim. Also compelling is the dissent of Lord Scott in Deutsche Morgan Grenfell plc $v I R C .{ }^{25}$ In cases where both mistake and entitlement are present, according to Burrows, 'the injustice by reason of the mistake is overridden by the fact that the money was owed anyway'. ${ }^{26}$ More fully: 'There is a fundamental interplay between unjust factors and enrichment owed by the claimant. This interplay normally results in the unjust factor being overridden by the enrichment being owed. ${ }^{27}$ These points are also made by Burrows in his Restatement of the English Law of Unjust Enrichment. According to section 3(6):

Enrichment, 8th edn (London, Sweet \& Maxwell, 2011) [1-09] and the discussion of justification grounds in chs 2 and 3.

${ }^{20}$ Burrows (n 18) 168-73.

21 eg, Mitchell, Mitchell and Watterson (n 19) [1-09], as well as the authorities cited in fn 24, including, eg, Portman Building Society v Hamlyn Taylor Neck (A Firm) [1998] 4 All ER 202 (CA), 206. The fourth 'question' identified in, eg, Banque Financière de la Cité v Parc (Battersea Ltd) [1999] 1 AC 221 (HL), 227, namely the existence of defences, is of course irrelevant to the elements of the claim.

${ }^{22}$ Burrows (n 18) 179 fn 49.

23 ibid 174, 184.

${ }^{24}$ Kleinwort Benson Ltd v Lincoln CC [1999] 2 AC 349 (HL) 407-08, referred to with approval by Arden LJ giving the judgment of the Court of Appeal in Test Claimants (n 16) [181].

${ }^{25}$ Deutsche Morgan Grenfell plc v IRC [2006] UKHL 49; [2007] 1 AC 558 [84]-[85].

${ }^{26}$ Burrows (n 18) 174.

27 ibid 184. See also Burrows (n 19) 88-89: 'the prima facie injustice established by the unjust factor is normally outweighed by the fact that the defendant is legally entitled to the enrichment. Overall, therefore, the enrichment is not unjust'. 
In general, an enrichment is not unjust if the benefit was owed to the defendant by the claimant under a valid contractual, statutory or other legal obligation. ${ }^{28}$

The notes on section 3(6) specify that:

[A]n unjust factor does not normally override a legal obligation of the claimant to confer the benefit on the defendant. The existence of the legal obligation means that the unjust factor is nullified so that the enrichment at the claimant's expense is not unjust. ${ }^{29}$

In the context of section 10 ('Mistake'), section 10(6) sets out this principle at a lower level of generality. ${ }^{30}$

Sections 11,12, 13, 14 and 19, dealing with duress, undue influence, exploitation of weakness, incapacity of the individual, and necessity, contain similar provisions.

Burrows' approach is to be contrasted with the way in which 'enrichment owed' is dealt with, for example, in the introductory chapter of the eighth edition of Goff \& Jones (under the heading 'Justifying Grounds'):

Under English law, a claimant will be entitled to restitution if he can show that a defendant was enriched at his expense, and that the circumstances are such that the law regards this enrichment as unjust. For example, a claimant will have a prima facie right to restitution where he has transferred a benefit to a defendant by mistake, under duress, or on a basis that fails. Nevertheless, the defendant can escape liability if another legal rule entitles him to keep the benefit, and this rule overrides the rule generated by the law of unjust enrichment which entitles the claimant to restitution ... Although the claimant would otherwise have a claim in unjust enrichment, the defendant's enrichment is justified by the statute or contract. $^{31}$

In this passage the authors appear to take the view that the existence of a justifying ground such as a statute or contract is extrinsic to the claimant's prima facie right to restitution; in other words, that 'enrichment owed' is a defence rather than a denial according to Goudkamp's typology. ${ }^{32}$ Graham Virgo takes a similar approach:

\footnotetext{
${ }^{28}$ A Burrows, A Restatement of the English Law of Unjust Enrichment (Oxford, Oxford University Press, 2012) 31.

${ }^{29}$ ibid 32.

30 ibid 63.

${ }^{31}$ Mitchell, Mitchell and Watterson (n 19) [1-12]. This passage is substantially repeated at the beginning of ch 2 , [2-01].

${ }^{32}$ See also C Mitchell, 'Unjust Enrichment' in A Burrows (ed), English Private Law, $3^{\text {rd }}$ edn (Oxford, Oxford University Press, 2013) 18.16-17.Having said that, the prominence of the treatment of justifying grounds in Goff \& Jones as a whole (in chs 2 and 3, immediately following the introduction) is perhaps difficult to reconcile with this view. $c f$ pp 9-10 below, where I consider the alternative possibility that both the presence of an unjust factor and the absence of a justifying ground constitute elements in the claimant's cause of action in English law.
} 
[O]nce the elements of the unjust enrichment claim have been established by the claimant, restitution will follow save where a basis for the defendant's retention of the enrichment can be identified by the defendant. ${ }^{33}$

Thus, it seems that several other commentators who continue to attach primary analytical significance to unjust factors treat 'enrichment owed' as a defence. This is also the view that appears to have been taken by the American Law Institute in the Restatement Third: Restitution and Unjust Enrichment. ${ }^{34}$

Burrows admits that it is 'arguably more elegant' to hive off the fundamental issue of the interplay between the unjust factors scheme and 'enrichment owed' to be solved by one or more defences. ${ }^{35}$ Nevertheless, such 'hiving off' 'gives the mistaken impression that where, for example, a contract has been entered into by a unilateral ("but for") mistake of the claimant, it is sufficient for the claimant who seeks restitution of money paid under the contract to show that the mistake it made was a unilateral mistake in entering into the contract and paying the money'. ${ }^{36}$ In other words, it accords insufficient weight to the distinction between transaction mistakes-mistakes in forming the intention to enter into a transaction-and execution mistakes-mistakes in carrying out such transactions. ${ }^{37}$ Furthermore, while in principle the legal burden of proving a defence should be on the defendant, 'it is surely clear that the legal burden of proving the invalidity of an apparent legal obligation, under which enrichment was owed by the claimant to the defendant, is most appropriately placed on the claimant'. ${ }^{38}$ Thus, for Burrows, 'the fact that the enrichment was owed by the claimant should be treated as an "upfront" matter relating to prima facie liability, with the legal burden being on the claimant, and not as a defence'. ${ }^{39}$

These points are compelling. However, there is at least one counter-argument: it is unclear whether injustice by reason of an unjust factor such as mistake-the element of 'unjust' - can really be 'overridden' or 'nullified' by the existence of a valid contractual, statutory or other obligation, or vice versa. ${ }^{40}$ In order for the defendant's entitlement to the

\footnotetext{
${ }^{33}$ Virgo (n 19) 477, 489. But note that elsewhere in this article (479 fn 16), he labels the presence of a legal ground a 'bar' rather than a defence, and in his Principles (n 18) 665, he states that 'a bar relates to the establishment of a cause of action [whereas] a defence only arise once the defendant has established the cause of action'. For further discussion of this apparent conflict, see Goudkamp and Mitchell (n 6) 152 fn 72.

${ }^{34}$ American Law Institute, Restatement Third: Restitution and Unjust Enrichment (St Paul, MN, American Law Institute Publishers, 2011) [62], discussed by Goudkamp and Mitchell (n 6) 151-53; Burrows (n 18) $179-82$.

${ }^{35}$ Burrows (n 18) 182.

36 ibid. cf Portman Building Society v Hamlyn Taylor Neck [1998] 4 All ER 202 (CA).

37 S Meier, Unjust Factors and Legal Grounds' in D Johnston and R Zimmermann (eds), Unjustified Enrichment: Key Issues in Comparative Perspective (Cambridge, Cambridge University Press, 2002) 37, 37-54. ${ }^{38}$ Burrows (n 18) 183.

39 ibid 184. Burrows makes also a third argument (183) regarding the potentially confusing relationship between 'enrichment legally owed' (if understood as a defence) and change of position.

${ }^{40}$ For discussion of exceptional cases where the claimant's legal obligation seems to have been outweighed by the unjust factor of mistake, as in, eg, Deutsche Morgan (n 25), see Burrows (n 18) 176-78.
} 
benefit to override or 'outweigh'41 the claimant's mistake, these two considerations would have to be commensurable. Yet it is not clear that this is the case. Mistake is a primary fact ${ }^{42}$ which is morally and legally relevant because it shows that the transfer of the benefit was in some sense involuntary: the impairment or vitiation of the claimant's consent or intent in making the transfer is the reason why it must be returned..$^{43}$ Indeed, underlying this unjust factor is a more fundamental commitment to the value of personal autonomy: where the claimant has conferred a benefit under the influence of a mistake, his autonomy is only imperfectly expressed-his plans for the distribution of his property have misfired-and it is this impairment of the claimant's autonomy which provides the moral justification for restitution. ${ }^{44}$ Entitlement, however, is a purely legal institution which draws on bodies of rules extraneous to the law of unjust enrichment, principally contract. ${ }^{45}$ Unlike in the case of mistake, the normative force of the defendant's entitlement to the benefit is not transparent: the reasons why entitlement blocks restitution are doctrinal rather than moral. On the one hand, implicit in the rule that restitution is excluded where enrichment is owed is some version of the principle of the subsidiarity of unjust enrichment to contract. ${ }^{46}$ This principle is important, indeed fundamental, but it is founded in the need for coherence within the law of obligations rather than in a direct appeal to values. On the other hand, the circularity problem raised by Burrows himself is a serious one: 'there is an upfront problem of inconsistency in saying that $C$ owed $D$ the enrichment and yet that $D$ must make restitution to $C^{\prime} .{ }^{47}$ But, once again, arguments concerning circularity within the law of obligations are purely doctrinal ones, of a different order from those underpinning the unjust factor of mistake. Of course, it remains possible to redefine 'unjust' in such a way that it comprises both kinds of arguments: Danie Visser has proposed this with respect to the term 'unjustified' in South African law. ${ }^{48}$ But such an approach threatens to rob the concept of 'unjust' of meaningful content. If it is to express anything more than the

\footnotetext{
${ }^{41}$ See, eg, ibid 177 for the use of 'outweigh' in this context.

42 cf L Smith, 'Unjust Enrichment: Big or Small?' in Degeling and Edelman (n 19) 35, 38.

${ }^{43} \mathrm{P}$ Birks, An Introduction to the Law of Restitution, revised edn (Oxford, Clarendon Press, 1989) 146-73. For more recent authority, see, eg, Burrows (n 28) s 3(2) and (3).

${ }^{44}$ cf Scott (n 14) 208-11.

45 cf L Smith, 'Demystifying Juristic Reasons' (2007) 45 Canadian Business Law Journal 281, 291. This is not to deny, of course, that contract can itself be construed as an expression of individual autonomy. But in the operation of a plea of entitlement or 'enrichment owed', the expression of this value is mediated through the existence of an objectively constitute legal obligation, rather than directly expressed, as in the case of mistake. $c f$ Scott (n 14) 210-11.

${ }^{46}$ On the slipperiness of this principle, see Mitchell, Mitchell and Watterson (n 19) [2-02]-[2-06]. What is meant here is simply that certain outcomes in the law of unjust enrichment are dictated by conclusions reached elsewhere.

47 Burrows (n 18) 176 fn 42.

48 Thus, he has proposed that in a case involving, for example, a mistaken payment, the descriptor 'unjustified' should incorporate both the element of mistake and the absence any obligation to make the payment: D Visser, Unjustified Enrichment (Cape Town, Juta, 2008) 171-93, especially 181, and 229-53, especially 251-53. See also my summary of Visser's 'third way' in Scott (n 14) 201-02.
} 
conclusion that restitution ought to be permitted, it does not seem that 'unjust' can be made to comprise such disparate considerations.

This point can be illustrated with reference to Deutsche Morgan Grenfell plc $v$ IRC itself. The claimant in this case had paid advance corporation tax (ACT) under a statutory scheme that was ultra vires the Revenue (the defendant) because, contrary to EU law, the scheme did not give Deutsche Morgan Grenfell (DMG) an option to avoid paying the tax by making a group income election. The House of Lords held that DMG was entitled to restitution from the Revenue for mistake even though it had a statutory duty to pay the tax unless and until it validly exercised a group income election which-because this had not been provided-it had not done. ${ }^{49}$ In one sense, of course, the Revenue was legally entitled to the tax. ${ }^{50}$ On the other hand, as the exaction of the ACT was unlawful in relation to companies in DMG's position because it did not allow them to make a group income election, and because it was clear that DMG would have made such an election if that had been permitted, it was arguably 'over-analytical' 51 to say that the tax was due unless and until that group income election was made. According to Burrows, 'The force of the unjust factor [mistake] clearly outweighed the force of the tax being due.'52 Thus, he argues, the normal rule-that the unjust factor is overridden by the enrichment's being owed ${ }^{53}$-did not apply. Yet it is unclear how it was that the claimant's mistake-which, incidentally, was said by Lord Hoffmann to be only a 'deemed mistake'54-came to 'outweigh' the defendant's entitlement to the money in this way. There is little sign of any such balancing exercise in the decision itself. The only question answered was as follows: was the defendant entitled to the money or not? The strength (or otherwise) of the claimant's mistake appears to have been irrelevant to the outcome of this inquiry.

This argument raises in turn a series of more fundamental issues: the competing claims of the unjust factor and absence of basis approaches on the English law of unjust enrichment, the relationship between these approaches, and in particular the possibility of a 'mixed approach' to enrichment liability in English law. According to Burrows himself: 'At a deeper level, this [ie, recognising that 'the fact that the enrichment was owed by the claimant should be treated as an "upfront" matter relating to prima facie liability'] involves

\footnotetext{
49 This summary is based on that of Burrows (n 18) 176-78. See also, eg, R Chambers, 'Deutsche Morgan Grenfell Group plc v IRC [2006] UKHL' (2006) 6 Oxford University Commonwealth Law Journal 227, 232-34; Stevens (n 19) 17-19; Burrows (n 19) 91.

${ }^{50}$ Burrows (n 28) 34.

${ }^{51}$ Deutsche Morgan (n 25) [143] (Lord Walker).

52 Burrows (n 18) 177.

53 ibid 184.

${ }^{54}$ Deutsche Morgan (n 25) [23]
} 
recognising that the unjust factors and the civilian "absence of basis" approaches are closer than has traditionally been thought. ${ }^{55}$ But at the same time:

[T]here is no need, as appears to be suggested by Goudkamp and Mitchell in their chapter in the present volume ... to see this approach as involving both unjust factors and the absence of legal basis. The idea of an enrichment owed to the claimant by the defendant [should read, 'by the claimant to the defendant'] is only one aspect of the absence of basis scheme ... nothing is said here, for example, about the unjust factors scheme being qualified by the law on gifts. ${ }^{56}$

The claim by Goudkamp and Mitchell to which Burrows refers is that 'it may be conceptually possible for a legal system to roll the two approaches into one by requiring claimants to show both the presence of an unjust factor and the absence of any legal ground for the transfer'. ${ }^{57}$ Burrows may well be correct when he says that treating 'enrichment owed' as an 'upfront matter' relevant to prima facie liability does not mean committing fully to the absence of basis scheme. The reasons he gives for treating 'enriched owed' in this waythat it is 'the best interpretation of English law', as well as the circularity problem set out above-are relatively specific. Moreover, his conception of 'enrichment owed' or (more fully) 'valid contractual, statutory or other legal obligation' appears to be much narrower than the standard understanding of 'basis' or 'legal ground' in civilian legal systems. ${ }^{58}$ Nevertheless, his claim that 'an enrichment is not unjust if the benefit was owed to the defendant' - his account of what he calls the 'fundamental interplay between unjust factors and enrichment owed'-does appear to require him to confront the relationship between unjust factors and the absence of a legal ground, and the possibility of a mixed approach to enrichment liability in English law.

Since the publication of the first edition of Peters Birks' Unjust Enrichment in 2003, this debate has tended to centre on the 'pyramid' metaphor used by Birks to describe the continuing relevance of unjust factors within his new absence of basis scheme. ${ }^{59}$ According to Birks: 'A pyramid can be constructed in which, at the base, the particular unjust factors such as mistake, pressure, and undue influence become reasons why, higher up, there is no basis for the defendant's acquisition, which is then the master reason why, higher up still, the enrichment is unjust and must be surrendered. ${ }^{\prime 60}$ As Birks made clear, according to this scheme, intent-based unjust factors such as mistake are 'subservient' to absence of basis,

\footnotetext{
${ }^{55}$ Burrows (n 18) 184. See also 168 and 176.

56 ibid 176 fn 42.

${ }^{57}$ Goudkamp and Mitchell (n 6) 153.

${ }^{58} \mathrm{cf}$ Scott (n 14) 7-9 (on the meaning of 'legal ground' in South African law) and 170-72 (on the meaning of 'legal ground' in German law), as well as J du Plessis, 'Towards a Rational Structure of Liability for Unjustified Enrichment: Thoughts from Two Mixed Jurisdictions' (2005) 122 South African Law Journal 142.

${ }^{59}$ P Birks, Unjust Enrichment, 2nd edn (Oxford, Clarendon Press, 2006) 116-17, as well as, eg, T Baloch, 'The Unjust Enrichment Pyramid' (2007) 123 LQR 636; Virgo (n 19).

${ }^{60}$ Birks (n 59) 116.
} 
'which itself then becomes an intermediate generalization between unjust factors and unjust'. ${ }^{61}$ In other words, a 'limited reconciliation' between unjust factors and absence of basis is possible if the relationship between these two analyses is understood as an explicitly hierarchical one. Beyond this, however, he was implacable: 'It would be absurd to suggest, as would be suggested by including absence of basis in the list of unjust factors, that by demonstrating two approaches applicable to that case... we have revealed the presence of two different causes of action.' 62 Further: 'They [absence of basis and unjust factors] are incompatibly alternative methods for deciding which enrichments are unjust. ${ }^{63}$

In my book, I attempt to refute this claim, arguing that Birks' pyramid gives insufficient weight to impairments to intent which are not also reasons for invalidity. ${ }^{64}$ Indeed, I arguein the words of Lionel Smith-that 'every legal system can and does mix the two approaches',65 since the unjust factors and absence of legal ground analyses each incorporate elements of the other. ${ }^{66}$ I still believe that this is true. However, it appears that in another sense, Birks was entirely right. Admittedly, in this subsection of Unjust Enrichment he had in his sights a rather specific proposition, namely the possibility of including absence of basis in the list of unjust factors alongside mistake, pressure etc. ${ }^{67}$ This possibility seemed to have been raised by certain of the swaps case or at least by certain commentators on those cases, and Birks was concerned to exclude it in particular. Nevertheless, his central claim has much wider application. It is indeed impossible to mix these two approaches at the same level, for the reasons set out above. ${ }^{68}$ The reasons for restitution represented by unjust factors and the reasons for retention represented by grounds or bases are incommensurable; they are indeed 'incompatibly alternative'. Thus, the orthodox unjust factors approach relegates the defendant's entitlement to the defences stage, just as the German absence of legal ground analysis deals with the unjust factor of mistake through the defence of knowledge set out in section 814 of the BGB. ${ }^{69}$

In fact, the only mixing or combining at the same level which is possible is that according to which both approaches (unjust factors and absence of basis) are applied in parallel or side by side: this may be what Goudkamp and Mitchell have in mind when they speak of a legal system rolling the two approaches into one by requiring claimants to show

\footnotetext{
61 ibid.

62 ibid 114.

63 ibid 115.

${ }^{64}$ Scott (n 14) 192-94.

${ }^{65}$ Smith (n 45) 304.

${ }^{66}$ These conclusions are summarised in Scott (n 14) 201-03.

${ }^{67}$ In Birks, Unjust Enrichment (n 59) 114-16 the subsection is bluntly entitled 'Absence of basis is not another unjust factor'.

${ }^{68}$ See pp 6-7 above.

${ }^{69}$ See, eg, Scott (n 14) 172.
} 
both the presence of an unjust factor and the absence of any legal ground' ${ }^{70}$ This appears to be what South African law does. ${ }^{71}$ According to the seminal decision in Willis Faber Enthoven (Pty) Ltd $v$ Receiver of Revenue, in the paradigm case involving the mistaken payment of tax, the plaintiff must demonstrate both the absence of any liability to make the transfer and the existence of a specific reason for restitution in the form of a (reasonable or excusable) mistake. ${ }^{72}$ Such a belt-and-braces approach leads to very conservative outcomes: indeed, South African law may embody that mythical system, hypothesised by Goudkamp and Mitchell, in which all liability rules have been assimilated to the elements of the action, rendering defences (or at least defences specific to the law of enrichment) superfluous. ${ }^{73}$ Nevertheless, although arguably over-determined, it is analytically coherent. There is no possibility of 'interplay' between the claimant's mistake and the defendant's entitlement: these considerations are wholly sealed off from one another, in that they are independent, equally weighted elements of the plaintiff's claim. ${ }^{74}$

\section{The Claimant's Cause of Action: 'Enrichment Owed' and the Absence of a Legal Ground}

\footnotetext{
${ }^{70}$ cf p 9 above. In support of this claim, see in particular their cross-reference (153 fn 76 ) to $\mathrm{J}$ du Plessis' account of the South African approach (ie, the 'traditional civilian approach') in 'Duress and Related Forms of Pressure: A Comparative Perspective' in Mitchell and Swadling (n 6) 102, as well as their remarks with respect to para 62 of the third American Restatement at p 152: 'One way to explain it [ie, the denial of restitution where a claimant who owes separate contractual debts to two creditors pays one while intending to pay the other] might be to say that the payee's enrichment is 'unjust' only if the payor's mistake is an 'invalidating mistake' of the kind identified in paragraph 5 and there is no basis for the payee's enrichment deriving from the contract. On this view, the absence of a contract between the parties is an element of the payor's action in unjust enrichment, and so the argument that the payee is contractually entitled to the money is a denial. Alternatively, if the making of an "invalidating mistake" is sufficient in itself to render the payee's enrichment "unjust", then the payee's appeal to his contractual rights is not a denial, because the "unjustness" of the payee's enrichment deriving from the mistake cannot be "nullified" by these rights. Instead, they provide a reason why restitution should not be awarded that is external to the definition of the action. On this view, para 62 describes a defence.' It seems to me that the first alternative canvassed comes rather close to the South African 'mixed approach', in that it appears to treat the absence of basis for the payee's enrichment as a separate element in the payor's claim. ${ }^{71}$ See generally Scott (n 14), especially ch 6, as well as H Scott, 'Rationalising the South African Law of Enrichment' (2014) 18 Edinburgh Law Review 433, especially 448-50.

${ }^{72}$ Willis Faber Enthoven (Pty) Ltd v Receiver of Revenue 1992 (4) SA 202 (A).

${ }^{73}$ Goudkamp and Mitchell (n 6) 143. For a sense of the paucity of defences in South African law, see J du Plessis, The South African Law of Unjustified Enrichment (Cape Town, Juta, 2012), at $161 \mathrm{ff}, 193 \mathrm{ff}, 204 \mathrm{ff}, 250$ ff, $306 \mathrm{ff}, 329 \mathrm{ff}, 341 \mathrm{ff}$, where a number of denials (with the exception of estoppel) are discussed under the heading 'defences' in the context of specific causes of action. Visser (n 48) does devote a chapter (ch 12) to defences, but several of these are discussed in theoretical terms only; of those currently recognised in South African law, only one, loss of enrichment, is specific to the law of enrichment. And, in fact, it is likely that loss of enrichment constitutes a denial rather than a defence: see ch 13 in du Plessis ('The Measure or Quantum of Enrichment Liability'), but $c f$ Visser (n 48) ch 12, especially $703 \mathrm{ff}$.

${ }^{74}$ See, eg, Scott (n 14) 203; see also Scott (n 71). Regarding the nature of the claimant's cause of action in the South African law of enrichment, see further s 3 below.
} 
To summarise, it seems that there is at least one objection to be made to Burrows' argument that 'enrichment owed' constitutes a denial rather than a defence in English law, in the sense that it serves to override the injustice generated by unjust factors such as mistake, namely what I have called the problem of incommensurability. However, even if it does constitute a denial, it is important to note that there are nevertheless crucial differences between the way in which 'enrichment owed' functions in English law and the way in which it functions in the context of the absence of legal ground approach, as for example in South African law. ${ }^{75}$ These differences relate to the allocation of the burden of pleading and proof as between claimant and defendant.

Taking as a starting point Burrows' claim that 'the legal burden of proving the invalidity of an apparent legal obligation, under which enrichment was owed by the claimant to the defendant, is most appropriately placed on the claimant ${ }^{\prime},{ }^{76}$ the following scheme might be tentatively proposed for the operation of 'enrichment owed' as a denial in the paradigm case of the mistaken payment in English law:

a) the claimant begins by pleading (and proving) that he made the payment by mistake;

b) the defendant pleads that the payment was in fact due under a valid contractual, statutory or other obligation;

c) it then falls to the claimant to prove that no such valid contact or other obligation exists.

It follows that in the case discussed by Burrows, in which a claimant who owes separate contractual debts to two creditors pays creditor A while intending to pay creditor $B$, provided that the defendant, creditor $A$, puts the existence of such an obligation in issue, the burden of proving the non-existence of the obligation falls on the claimant. On the other hand, if the claimant succeeds in proving the existence of a 'but for' mistake and creditor A wholly fails to raise the fact that the payment was due to him in terms of a valid contractual obligation, the claimant will succeed solely by virtue of his causative mistake. In other words, the claimant is under no obligation to plead the absence of such a valid obligation in the first instance. The existence of such an obligation is relevant to the 'unjust' element of the claimant's claim or action, in that it serves to rebut it, but its absence is not an element of his claim; it is not an ingredient in his cause of action.

This is to be contrasted with the absence of legal ground element applied, for example, in South African law. As discussed in the previous section, and as cases such as Willis Faber Enthoven and the more recent decision of the Supreme Court of Appeal in

\footnotetext{
${ }^{75}$ Indeed, Burrows himself makes this point explicitly, ie, that treating 'enrichment owed' as an 'upfront matter' relevant to prima facie liability does not mean committing fully to the absence of basis scheme. See Burrows (n 18) 176 fn 42 and cf p 8-9 above.

76 ibid 183.
} 
Affirmative Portfolios CC $v$ Transnet Ltd $t /$ a Metrorail ${ }^{77}$ show, the South African condictio indebiti arises from the absence of any liability on the part of the plaintiff to make the transfer, in combination with the existence of a specific reason for restitution such as mistake. ${ }^{78}$ The plaintiff cannot make out even a prima facie case without pleading the absence of liability - that the transfer was indebitum in the sense required-and, at least in cases involving an apparent contractual or other obligation, without proving the nonexistence or invalidity of that obligation. ${ }^{79}$ The non-liability of the plaintiff (in combination with his mistake) constitutes part of the gist of his claim: an ingredient in his cause of action. Thus, the degree of uncertainty surrounding the existence of a continuing statutory obligation to pay the tax in question in the Deutsche Morgan Grenfell case is inconceivable in South African law. Indeed, the contrast with English law is obvious simply from the use of negative formulations such as 'absence of legal ground', 'non-liability' and indebitum, as opposed to the positive formulations 'entitlement' and 'owed': the English rule is 'the payee cannot be said to have been unjustly enriched if he was entitled to receive the sum paid to him', ${ }^{80}$ not 'an indebitum paid as a result of a mistake ... may be recovered' ${ }^{81}$ This point is linked to the wider significance of the absence of legal ground concept as the 'golden thread' running through this entire body of South African law. ${ }^{82}$ While non-liability constitutes the gist of the plaintiff's condictio indebiti, in combination with other factors such as mistake, it also constitutes a necessary condition for restitution throughout the law of enrichment. ${ }^{83}$

Of course, in the very common case in which the claimant's mistake concerns his liability to pay, proof of that mistake will necessarily involve pleading and proving the absence or invalidity of an apparent contractual or other obligation to make the payment. In cases such as these, there is no difference in practice between the absence of a legal ground as an ingredient in the claimant's cause of action and 'enrichment owed' as a denial. Nevertheless, it seems important not to neglect the distinction between causes of action (what the claimant must plead and prove in order to make out a prima facie claim) and denials (a plea by the defendant which serves to rebut one of the elements of that claim). Although in the case of a denial the defendant's plea is not extrinsic to or independent of the claimant's action, as in the case of a defence, but rather goes to one of its elements, it is nevertheless analytically significant that the matter is for the defendant to plead rather than

\footnotetext{
${ }^{77}$ Affirmative Portfolios CC v Transnet Ltd t/a Metrorail 2009 (1) SA 196 (SCA).

${ }^{78}$ See generally Scott (n 14) and (for a more succinct account) Scott (n 71).

$79 \mathrm{See}$, eg, the explicit dictum regarding onus in Willis Faber (n 72) 224. On the distribution of the burden of proof with respect to the absence of a legal ground in German law, see, eg, S Meier, 'No Basis: A Comparative View' in A Burrows and Lord Rodger of Earlsferry (eds), Mapping the Law: Essays in Memory of Peter Birks (Oxford, Oxford University Press, 2006) 343, 350-51.

${ }^{80}$ Kleinwort Benson v Lincoln (n 24) 407-08 (Lord Hope).

${ }^{81}$ Willis Faber (n 72) 224.

${ }^{82}$ cf Stevens (n 19) especially 16, 33-34.

83 cf Scott (n 71) 435-37.
} 
the claimant. To draw a parallel with the law of defamation, it is undoubtedly meaningful that the falsehood of the defendant's allegation is not part of the claimant's cause of action, the gist of his claim in defamation, even if, as Goudkamp argues, the truth of that allegation is not a matter extrinsic to the elements of the claim, but rather goes to the element of damage. ${ }^{84}$

\section{Conclusion}

James Goudkamp's analysis of defences is a valuable new analytical tool in the hands of obligations lawyers. Formulated in the context of tort, it is equally useful in the context of unjust enrichment, as his and Charles Mitchell's analysis in The Restatement Third: Restitution and Unjust Enrichment shows. ${ }^{85}$ If a particular rule-say, change of position or good consideration - is found to be a defence rather than a denial, this implies an important judgement about the nature of the claimant's action itself, namely that it arises independently of that rule. Thus, the question addressed by Andrew Burrows in his contribution to the same volume, ${ }^{86}$ that is, whether good consideration-or rather 'enrichment owed' - is a defence or a denial, raises issues of central analytical importance in the English law of unjust enrichment, issues regarding the basis of liability itself.

Burrows takes the view that 'enrichment owed' is a denial; in other words, an 'upfront' matter relating to prima facie liability, specifically to the element of 'unjust': 'the prima facie injustice established by the unjust factor is normally outweighed by the fact that the defendant is legally entitled to the enrichment. Overall, therefore, the enrichment is not unjust' ${ }^{87}$ Burrows' arguments in support of his view are compelling. However, I have argued in response that an unjust factor such as mistake and the defendant's entitlement to the benefit are after all not commensurable considerations capable of overriding or outweighing one another. Whereas mistake is a primary fact, morally and legally relevant because it shows that the transfer of the benefit was in some sense involuntary, entitlement is a legal institution which draws on bodies of rules extraneous to the law of unjust enrichment, principally contract; the reasons why 'enrichment owed' blocks restitution are doctrinal rather than moral.

This point raises in turn a more fundamental issue, namely the competing claims of the unjust factor and absence of basis approaches on the English law of unjust enrichment, and in particular the possibility of a 'mixed approach' to enrichment liability. Since the

\footnotetext{
${ }^{84}$ cf Goudkamp (n 1) 62-65.

85 Once again, the full citation is James Goudkamp and Charles Mitchell, 'Denials and Defences in the Law of Unjust Enrichment' in Mitchell and Swadling (n 6) ch 6.

${ }^{86}$ See, again, Burrows (n 18).

${ }^{87}$ Burrows (n 19) 88-89.
} 
publication of Peter Birks' Unjust Enrichment, this debate has tended to centre on the pyramid metaphor used by Birks to describe the continuing relevance of unjust factors within his new absence of basis scheme. Although Birks believed that a limited reconciliation' between the unjust factors and absence of basis approaches was possible, this was the case only if the relationship between these two analyses was understood as an explicitly hierarchical one: beyond that, he took the view that 'they are incompatibly alternative methods for deciding which enrichments are unjust' ${ }^{88}$ On reflection, this turns out to be correct: it is indeed impossible to mix these two approaches at the same level, because these two sets of considerations-the reasons for restitution represented by unjust factors and the reasons for retention represented by grounds or bases-are incommensurable. The only mixing or combining at the same level which is possible is that according to which both approaches (unjust factors and absence of basis) are applied in parallel, the claimant's mistake and the defendant's entitlement treated as independent, equally weighted elements of the claim. This, it seems, is what South African law has elected to do.

Finally, even if Burrows is correct and 'enrichment owed' does constitute a denial rather than a defence, it is important to note that there are nevertheless crucial differences between the way in which the issue of entitlement is treated in English law and the way in which it is treated in the context of an absence of legal ground approach, as for example in South African law. Working with the paradigm case of the mistaken payment, even if the legal burden of proving the invalidity of an apparent legal obligation were placed on the claimant rather than the defendant, as Burrows suggests it should be, it would generally be for the defendant to put the existence of such an obligation in issue in the first instance; if he failed to do so, the claimant would succeed merely by virtue of his mistake. In South African law, on the other hand, the plaintiff cannot make out even a prima facie case without pleading the absence of any liability on his part to make the transfer in question. The non-liability of the plaintiff (in combination with his mistake) constitutes the gist of his claim: his cause of action. This shows that however analytically significant the distinction between denials and defences, it is equally important not to neglect the distinction between causes of action and denials. Although in the case of a denial the defendant's plea is not extrinsic to the plaintiff's action, as in the case of a defence, but rather goes to one of its elements, it is nevertheless analytically significant that the matter in question is for the defendant rather than the claimant to plead.

\footnotetext{
${ }^{88}$ Birks (n 59) 115.
} 